\title{
Pengaruh Pendapatan Asli Daerah dan Dana Alokasi Khusus terhadap Belanja Daerah di Kota Banda Aceh
}

\author{
Fanny Nailufar \\ Fakultas Ekonomi, Universitas Serambi Mekkah \\ e-mail: fannynailufar24@gmail.com \\ Sufitrayati \\ Fakultas Ekonomi, Universitas Serambi Mekkah \\ e-mail: sufitrayati@serambimekkah.a.c.id
}

\begin{abstract}
The purpose of this study was to determine the effect of Local Revenue and Special Allocation Funds on Regional Expenditures in the city of Banda Aceh from 2010-2015. The data used in this study was secondary data, which was obtained from financial statements for the financial year ending on December 31, 2010 to 2015, which was obtained directly from the DPKAD of Banda Aceh City. The data analysis method used was multiple linear regression. The results of this study indicated that Regional Original Income and Special Allocation Funds simultaneously influence Regional Expenditures in the city of Banda Aceh in the period 2010-2015. Local revenue had a positive effect on regional expenditure with an influence of $306.4 \%$. The special allocation funds had a positive effect on regional expenditure with an influence of 1365.6\%. Suggestions for further research are expected to include other factors that are thought to influence regional spending such as general allocation funds. From the results of this study, it is expected that the Regional Original Revenues can increase, the government of the City of Banda Aceh is expected to increase the collection of Regional Taxes, Regional Retributions and other legitimate PAD (Original Local Government Revenue) intensively and actively up to a percentage of $100 \%$.
\end{abstract}

Keywords: Original Local Government Revenue, Special Allocation Funds and Regional Expenditure

\section{PENDAHULUAN}

Dengan diberlakukannya otonomi daerah maka pemerintah daerah dituntut untuk bisa melaksanakan fungsi dan perannya sesuai dengan kewenangan yang dimiliki. Kebijakan pemerintah Indonesia tentang otonomi daerah tersebut dipandang sangat demokratis dan memenuhi aspek-aspek desentralisasi sesungguhnya. Desentralisasi sendiri mempunyai tujuan untuk lebih meningkatkan kesejahteraan dan pelayanan kepada masyarakat pengembangan kehidupan berdemokrasi, keadilan, pemerataan, dan pemeliharaan hubungan yang serasi antara pusat dan daerah serta antar daerah. Hal tersebut sesuai dengan ketentuan umum di Undang-Undang (UU) Otonomi Daerah Nomor 32 Tahun 2004 tentang Pemerintah Daerah yang telah menggantikan UU Nomor 22 Tahun 1999. Serta UU Nomor 33 Tahun 2004 tentang Perimbangan Keuangan antara Pemerintah Pusat dan Pemerintah Daerah yang telah menggantikan UU Nomor 25 Tahun 1999.

Dalam UU Nomor 32 Tahun 2004 disebutkan pada pasal 155 ayat 1 yang berbunyi "Penyelenggaraan urusan pemerintahan yang menjadi kewenangan daerah didanai dari dan atas beban anggaran pendapatan dan belanja daerah". Ayat 2 
berbunyi "Penyelenggaraan urusan pemerintahan yang menjadi kewenangan daerah didanai dari dan atas beban anggaran pendapatan dan belanja negara". Sedangkan pada ayat 3 berbunyi "Administrasi pendanaan penyelenggaraan urusan pemerintahan sebagaimana yang dimaksud ayat 1 dilakukan secara terpisah dari administrasi pendanaan penyelenggaraan urusan pemerintahan sebagaimana dimaksud pada ayat 2".

UU Nomor 33 Tahun 2004 menjelaskan bahwa pemerintah pusat akan mentransfer Dana Perimbangan yang terdiri dari Dana Alokasi Umum (DAU), Dana Alokasi Khusus (DAK), dan bagian daerah dari Dana Bagi Hasil (DBH) yang terdiri dari pajak dan sumber daya alam. Selain dana perimbangan tersebut, pemerintah daerah mempunyai sumber pendanaan sendiri berupa Pendapatan Asli Daerah (PAD), Pembiayaan, dan lainlain PAD yang sah. Kebijakan penggunaan semua dana tersebut diserahkan kepada pemerintah daerah. Dana transfer dari pemerintah pusat diharapkan dapat dipergunakan secara efektif dan efisien oleh pemerintah daerah dalam rangka peningkatan pelayanan pada masyarakat. Kebijakan yang ditetapkan oleh pemerintah daerah dalam penggunaan dana tersebut sudah seharusnya dilakukan secara transparan dan akuntabel.

Belanja daerah dipergunakan dalam rangka pelaksanaan urusan pemerintahan yang menjadi kewenangan provinsi atau kabupaten/kota yang terdiri dari urusan wajib dan urusan pilihan yang ditetapkan dengan ketentuan perundang-undangan. Belanja penye-lenggaraan urusan wajib diprioritaskan untuk melindungi masyarakat dalam upaya memenuhi kewajiban daerah yang diwujud kan dalam bentuk peningkatan pelayanan dasar seperti pendidikan, kesehatan, fasilitas sosial dan fasilitas umum yang layak serta mengembangkan sistem jaminan sosial (Peraturan Pemerintah Nomor 58 Tahun 2005).

Menurut Peraturan Menteri Dalam Negeri Nomor 13 Tahun 2006 tentang Pedoman Pengelolaan Keuangan Daerah, Belanja Daerah adalah semua pengeluaran dari rekening kas umum daerah yang mengurangi ekuitas dana. Belanja Daerah merupakan kewajiban daerah dalam satu tahun anggaran dan tidak akan diperoleh pembayarannya kembali oleh daerah. Disamping itu belanja daerah dipengaruhi oleh pendapatan asli daerah.

Pendapatan Asli Daerah merupakan akumulasi dari Pos Penerimaan Pajak yang berisi Pajak Daerah dan Pos Retribusi Daerah, Pos Penerimaan Non Pajak yang berisi hasil perusahaan milik daerah, Pos Penerimaan Investasi serta Pengelolaan Sumber Daya Alam (Isdijoso, 2002). Identifikasi sumber Pendapatan Asli Daerah adalah meneliti, menentukan dan menetapkan mana yang sesungguhnya menjadi sumber Pendapatan Asli Daerah dengan cara meneliti dan mengusahakan serta mengelola sumber pendapatan tersebut dengan benar sehingga memberikan hasil yang maksimal (Elita dalam Pratiwi, 2007).

Menurut UU No. 17 Tahun 2003, pendapatan daerah adalah hak pemerintah daerah yang diakui sebagai penambah nilai kekayaan bersih. Pendapatan Daerah (basis kas) adalah penerimaan oleh bendahara umum daerah atau oleh entitas pemerintah lain yang menambah ekuitas dana lancar dalam periode tahun anggaran bersangkutan. Penerimaan tersebut menjadi hak pemerintah dan tidak perlu dibayar kembali oleh pemerintah. Pendapatan Daerah (basis akrual) adalah hak pemerintah yang diakui sebagai penambah nilai kekayaan bersih. Yuwono dkk. (2005:107) menyatakan bahwa pendapatan daerah adalah semua penerimaan kas yang menjadi hak daerah dan diakui sebagai penambahan nilai kekayaan bersih dalam satu tahun anggaran dan tidak perlu dibayar kembali oleh pemerintah. Lebih lanjut Halim (2007:96) menyatakan bahwa Pendapatan Asli Daerah (PAD) merupakan semua penerimaan daerah yang berasal dari sumber ekonomi asli daerah.

Dana Alokasi Khusus (DAK) adalah dana yang bersumber dari pendapatan APBN yang dialokasikan kepada daerah tertentu dengan tujuan untuk membantu mendanai kegiatan khusus yang merupakan urusan daerah dan sesuai dengan prioritas nasional. 
Dana Alokasi Khusus merupakan bagian dari Dana Perimbangan sesuai dengan UU No. 33 Tahun 2004 tentang Perimbangan Keuangan antara Pemerintah Pusat dan Pemerintah Daerah.

Pengalokasian dana alokasi khusus diprioritaskan untuk daerah yang memiliki kemampuan fiskal rendah atau dibawah ratarata nasional. Kemampuan fiskal daerah didasarkan pada selisih antara realisasi penerimaan umum daerah dengan belanja pegawai negeri sipil daerah pada anggaran pembelanjaan daerah tahun anggaran.

Fenomena saat ini setiap daerah mempunyai kemampuan keuangan yang tidak sama dalam mendanai kegiatan-kegiatannya, hal ini menimbulkan ketimpangan fiskal antar satu daerah dengan daerah lainnya. Oleh karena itu, untuk mengatasi ketimpangan fiskal ini Pemerintah mengalokasikan dana yang bersumber dari APBN untuk mendanai kebutuhan daerah di dalam pelaksanaan desentralisasi. Salah satu dana perimbangan dari pemerintah ini adalah Dana Alokasi Umum dan Dana Alokasi Khusus yang pengalokasiannya menekankan pada aspek pemerataan dan keadilan yang selaras dengan penyelenggaraan urusan pemerintahan (UU 32/2004). Dengan adanya transfer dana dari pusat ini diharapkan pemerintah daerah bisa lebih mengalokasikan PAD yang didapatnya untuk membiayai belanja daerah di wilayahnya. Berdasarkan uraian sebelumnya, maka penulis tertarik untuk melakukan penelitian dengan topik pengaruh Pendapatan Asli Daerah dan Dana Alokasi Khusus terhadap Belanja Daerah Pada Kota Banda Aceh Periode 2010-2015.

\section{Pendapatan Asli Daerah (PAD)}

Menurut UU No. 17 Tahun 2003, pendapatan daerah adalah hak pemerintah daerah yang diakui sebagai penambah nilai kekayaan bersih. Pendapatan Daerah (basis kas) adalah penerimaan oleh bendahara umum daerah atau oleh entitas pemerintah lain yang menambah ekuitas dana lancar dalam periode tahun anggaran bersangkutan. Penerimaan tersebut menjadi hak pemerintah dan tidak perlu dibayar kembali oleh pemerintah.
Pendapatan Daerah (basis akrual) adalah hak pemerintah yang diakui sebagai penambah nilai kekayaan bersih. Yuwono dkk. (2005:107) menyatakan bahwa pendapatan daerah adalah semua penerimaan kas yang menjadi hak daerah dan diakui sebagai penambahan nilai kekayaan bersih dalam satu tahun anggaran dan tidak perlu dibayar kembali oleh pemerintah. Lebih lanjut, Halim (2007:96) menyatakan bahwa Pendapatan Asli Daerah (PAD) merupakan semua penerimaan daerah yang berasal dari sumber ekonomi asli daerah.

Sesuai UU No.33 Tahun 2004, apabila kebutuhan pembiayaan suatu daerah lebih banyak diperoleh dari subsidi atau bantuan dari pusat, dan nyata-nyata kontribusi PAD terhadap kebutuhan pembiayaan tersebut sangat kecil, maka dapat dipastikan bahwa kinerja keuangan daerah itu masih sangat lemah. Kecilnya kontribusi PAD terhadap kebutuhan pembiayaan sebagaimana yang tertuang dalam APBD merupakan bukti kekurang mampu daerah dalam mengelola sumber daya perekonomian terutama sumbersumber pendapatannya.

Pasal 157 UU No. 32 Tahun 2004 dan Pasal 6 UU No. 33 Tahun 2004 menjelaskan bahwa sumber Pendapatan Asli Daerah terdiri atas hasil Pajak Daerah, hasil Retribusi Daerah, hasil Pengelolaan Kekayaan yang Dipisahkan, dan PAD lainnya yang sah. Dengan penggalian dan peningkatan pendapatan asli daerah diharapkan pemerintah daerah mampu meningkatkan kemampuannya juga dalam penyelenggaraan urusan daerah.

\section{Pendapatan Pajak Daerah}

Halim (2007:96) menyatakan Pajak Daerah merupakan Pendapatan Daerah yang berasal dari pajak. Lebih lanjut, Simanjuntak (2007:32) menyatakan bahwa Pajak Daerah adalah pajak-pajak yang dipungut oleh daerah-daerah seperti propinsi, kabupaten maupun kotamadya berdasarkan peraturan daerah masing-masing dan hasil pemungutannya digunakan untuk pembiayaan rumah tangga daerahnya masing-masing. Kesit (2009:2) menyatakan bahwa Pajak Daerah merupakan iuran wajib yang dilakukan oleh 
orang pribadi atau badan tanpa imbalan langsung yang seimbang, yang dapat dipaksakan berdasarkan undang-undang yang berlaku, yang hasilnya digunakan untuk membiayai penyelenggaraan pemerintah daerah dan pembangunan daerah.

Wewenang mengenakan pajak atas penduduk untuk membiayai layanan masyarakat merupakan unsur penting dalam pemerintahan daerah. Diungkapkan oleh Devas et.al. (2009:58) bahwa sistem perpajakan yang dipakai sekarang ini banyak mengandung kelemahan, dan tampaknya bagian terbesar dari pajak daerah lebih banyak menimbulkan beban ketimbang menghasilkan penerimaan bagi masyarakat. Untuk itu pemerintah perlu melakukan perubahan sistem pajak daerah merupakan langkah logis untuk langkah berikutnya.

Pembaharuan yang dilakukan oleh pemerintah misalnya dengan diterbitkannya UU No. 34 Tahun 2004 tentang pajak dan retribusi sebagai perubahan UU No. 18 Tahun 1997. Dengan diberlakukannya UU No. 34 Tahun 2004 ini jenis pajak daerah jumlahnya menjadi berkurang. Terakhir pemerintah menerbitkan UU No. 33 Tahun 2004 tentang perimbangan keuangan antara pemerintah pusat dan pemerintah daerah. Dalam UndangUndang tersebut dijelaskan tentang pembagian hasil Pajak Bumi dan Bangunan (PBB) dan Bea Perolehan Hak Atas Tanah dan Bangunan (BPHTB) serta pembagian berbagai penerimaan Negara.

Davey (2008:41) menjelaskan bahwa keberhasilan dalam mengelola sumbersumber penerimaan pajak daerah tergantung pada kemampuan pemerintah daerah itu sendiri dalam mengoptimalkan faktor- faktor yang turut menentukan keberhasilan tersebut. Devas et al. (2009:72) memberi penjelasan bahwa kemampuan menghimpun dana adalah perbandingan antara penerimaan dari pajak dengan restribusi atau disebut dengan upaya (tax effort).

Mardiasmo (2002:147) mengungkapkan bahwa untuk mengurangi ketergantungan terhadap pembiayaan dari pemerintahan pusat, pemerintahan daerah perlu diberikan otonomi dan keleluasan daerah. Langkah penting yang harus dilakukan untuk meningkatkan penerimaan pajak daerah adalah dengan menghitung besaran potensi penerimaan pajak daerah yang rill yang dimiliki oleh daerah tersebut, sehingga bisa diketahui peningkatan kapasitas pajak (tax capacity) daerah. Peningkatan kapasitas pajak pada dasarnya adalah optimalisasi sumbersumber pendapatan daerah.

\section{Pendapatan Retribusi Daerah}

Pemungutan retribusi dibayar langsung oleh mereka yang menikmati suatu pelayanan, dan biasanya dimaksudkan untuk menutup seluruh atau sebagai dari biaya pelayanannya. Besarnya retribusi seharusnya (lebih kurang) sama dengan nilai layanan yang diberikan. Menurut Sumitro (2007:15), Retribusi ialah pembayaran pada negara yang dilakukan oleh mereka yang menggunakan jasa-jasa.

Lebih lanjut, Syamsi (2008:221) mengatakan bahwa Retribusi adalah iuran masyarakat tertentu (individu bersangkutan) yang ditetapkan berdasarkan peraturan pemerintah yang prestasinya ditunjuk secara langsung, dan pelaksanaannya bisa secara dipaksakan. Dengan kata lain yang lebih sederhana, retribusi adalah pungutan yang dibebankan pada seseorang karena menikmati jasa secara langsung.

Davey (2008:31) mengatakan bahwa Retribusi merupakan sumber penerimaan yang sudah umum bagi semua bentuk Pemerintahan Regional, restribusi tersebut mungkin juga merupakan sumber utama dari pendapatan badan-badan pembangunan daerah. Sedangkan Redjo (2008:89) memberi pendapat bahwa retribusi adalah suatu pembayaran dari rakyat kepada pemerintah dimana kita dapat melihat adanya hubungan antara balas jasa yang diterima langsung dengan adanya pembayaran retribusi tersebut, misalnya uang langganan air minum, uang langganan listrik dan lain-lain. Koswara (2001:191) menjelaskan bahwa retribusi daerah adalah imbalan atas pemakaian atau manfaat yang diperoleh secara langsung seseorang atau badan atau jasa layanan, pekerjaan, pemakaian barang, atau izin yang diberikan pemerintah daerah. Simanjuntak 
(2003:34) menyatakan bahwa retribusi daerah merupakan iuran rakyat kepada pemerintah berdasarkan undang-undang (yang dapat dipaksakan) dengan mendapat jasa balik atau kontra prestasi dari pemerintah yang secara langsung ditunjuk.

Mengenai potensi Retribusi Daerah, Koswara (2001:194) memaparkan bahwa seperti halnya dengan pajak daerah, hanya dengan beberapa jenis retribusi yang secara efektif berperan sebagai sumber pendapatan daerah. Walaupun demikian Devas et al. (2009:92) mengatakan bahwa Retribusi merupakan sumber pendapatan yang sangat penting dan hasil retribusi hampir mencapai setengah dari seluruh pendapatan daerah. Dalam dimensi potensi daerah yang demikian itu, pemerintahan daerah hendaknya dapat mengembangkan inisiatif dan upaya untuk meningkatkan penerimaan Retribusi Daerah. Upaya ini antara lain dilakukan dengan cara memberikan pelayanan publik secara profesional dan mampu memberikan kepuasan kepada setiap penerimaan pelayanan.

Davey (2008:148) mengungkapkan beberapa pendapat mungkin akan timbul pada elastisitas retribusi yang harus responsive pada pertumbuhan penduduk dan pendapatan. Hal ini umumnya dipengaruhi oleh pertumbuhan permintaan atau konsumsi akan suatu pelayanan. Dalam konteks yang demikian itu, pengelolaan sumber-sumber PAD dari jenis retribusi tentu mempunyai konsekwensi yang harus dipikirkan oleh pemerintah daerah. Artinya pemerintah daerah tidak boleh memikirkan bagaimana memperoleh pendapatan yang sebesarbesarnya dari pemungutan retribusi, tetapi pemerintah daerah bertanggungjawab atas konsekuensi pemungutan retribusi tersebut.

\section{Hasil Pengelolaan Kekayaan Daerah Yang Dipisahkan}

Sesuai UU No. 33 Tahun 2004, jenis hasil pengelolaan kekayaan daerah yang dipisahkan dapat dirinci menurut obyek pendapatan yang mencakup bagian laba atas penyertaan modal pada perusahaan milik daerah/BUMD. Bagian laba atas penyertaan modal pada perusahaan milik pemerintah/
BUMN dan bagian laba atas penyertaan modal pada perusahaan milik swasta atau kelompok usaha masyarakat.

Perusahaan daerah adalah semua perusahaan yang didirikan seluruhnya atau sebagian dengan modal daerah. Tujuannya adalah dalam rangka menciptakan lapangan kerja atau mendorong perekonomian daerah dan merupakan cara yang efisien dalam melayani masyarakat dan untuk menghasilkan penerimaan daerah. Bagian keuntungan usaha daerah atau laba usaha daerah adalah keuntungan yang menjadi hak pemerintah daerah dari usaha yang dilakukannya. Jenis pendapatan ini dirinci menurut objek pendapatan yang mencakup (UU No. 33/2004):

1. Bagian laba atas penyertaan modal pada perusahaan milik daerah/BUMD.

2. Bagian laba atas penyertaan modal pada perusahaan milik negara/BUMN.

3. Bagian laba atas penyertaan modal pada perusahaan milik swasta atau kelompok usaha masyarakat.

\section{Lain-Lain Pendapatan Asli Daerah yang Sah}

Jenis lain-lain Pendapatan Asli Daerah yang Sah sesuai UU No. 33 Tahun 2004 disediakan untuk menganggarkan penerimaan daerah yang tidak termasuk dalam jenis Pajak Daerah, Retribusi Daerah, dan Hasil Pengelolaan Kekayaan Daerah yang Dipisahkan dirinci menurut obyek pendapatan yang antara lain: hasil penjualan kekayaan daerah yang tidak dipisahkan secara tunai atau angsuran/ cicilan, jasa giro, pendapatan bunga, penerimaan atas tuntutan ganti kerugian daerah, penerimaan komisi, potongan ataupun bentuk lain sebagaimana akibat dari penjualan atau pengadaan barang dan jasa oleh daerah, penerimaan keuntungan dari selisih nilai tukar rupiah terhadap mata uang asing.

\section{Dana Alokasi Khusus (DAK)}

Dana Alokasi Khusus berasal dari APBN dan dialokasikan ke kabupaten/kota untuk membiayai kebutuhan tertentu yang bersifat khusus, tertanggung pada tersedianya dana dalam APBN (Saragih, 2005:84). 
Kebutuhan khusus ini misalnya, kebutuhan di kawasan transmigrasi, pembangunan jalan di kawasan terpencil, pembangunan irigasi primer, dan saluran drainase primer.

Dana Alokasi Khusus adalah dana yang bersumber dari pendapatan APBN yang dialokasikan kepada daerah tertentu dengan tujuan untuk membantu mendanai kegiatan khusus yang merupakan urusan daerah dan sesuai dengan prioritas nasional. Dana Alokasi Khusus merupakan bagian dari Dana Perimbangan sesuai dengan UU No. 33 Tahun 2004 tentang Perimbangan Keuangan antara Pemerintah Pusat dan Pemerintah Daerah.

DAK bertujuan untuk mendanai kegiatan khusus yang menjadi urusan daerah dan merupakan prioritas nasional, sesuai dengan fungsi yang merupakan perwujudan tugas kepemerintahan di bidang tertentu, khususnya dalam upaya-upaya pemenuhan kebutuhan sarana dan prasarana pelayanan dasar masyarakat (Mardiasmo, 2002:98). Pengalokasian DAK diprioritaskan untuk daerah yang memiliki kemampuan fiskal rendah atau dibawah rata-rata nasional. Kemampuan fiskal daerah didasarkan pada selisih antara realisasi penerimaan umum daerah dengan belanja pegawai negeri sipil daerah pada APBD tahun anggaran.

Yani (2008:172) menyatakan bahwa DAK dialokasikan untuk membantu daerah mendanai kebutuhan fisik sarana dan prasarana yang merupakan prioritas nasional dibidang pendidikan, kesehatan, infrastruktur (jalan, irigasi, dan air berih), kelautan dan perikanan, pertanian, prasarana pemerintahan daerah, serta lingkungan hidup.

\section{Alokasi Belanja Daerah}

Belanja Daerah menurut Kepmendagri Nomor 29 Tahun 2002 adalah semua pengeluaran kas daerah dalam periode tahun anggaran tertentu yang menjadi beban daerah. Menurut UU No. 23 tahun 2002, Belanja daerah adalah kewajiban pemerintah daerah yang diakui sebagai pengurang nilai kekayaan bersih pada tahun anggaran yang bersangkutan. Belanja daerah (basis kas) adalah semua pengeluaran oleh bendahara umum daerah yang mengurangi ekuitas dana lancar dalam periode tahun anggaran bersangkutan yang tidak akan diperoleh pembayarannya kembali oleh pemerintah. Belanja Daerah (basis akrual) adalah kewajiban pemerintah yang diakui sebagai pengurang nilai kekayaan bersih.

Halim (2007:322) menyatakan bahwa Belanja Daerah adalah kewajiban pemerintah mengurangi nilai kekayaan bersih. Lebih lanjut, Yuwono (2005:108) menyatakan belanja daerah adalah semua pengeluaran kas daerah atau kewajiban yang diakui sebagai pengurang nilai kekayaan bersih dalam periode satu tahun anggaran yang tidak akan diperoleh pembayarannya kembali oleh pemerintah.

Belanja Daerah dipergunakan dalam rangka pelaksanakan urusan pemerintahan yang menjadi kewenangan provinsi atau kabupaten/kota yang terdiri dari urusan wajib dan urusan pilihan yang ditetapkan berdasarkan peraturan perundang-undangan (Yuwono, 2005:117). Belanja daerah dikelompokkan ke dalam belanja tidak langsung dan belanja langsung. Belanja tidak langsung merupakan belanja yang dianggarkan tidak terkait secara langsung dengan pelaksanaan program dan kegiatan. Sementara itu, belanja langsung merupakan belanja yang dianggarkan terkait secara langsung dengan pelaksanaan program dan kegiatan.

Di dalam ketentuan umum UndangUndang No. 17 Tahun 2003 pada pasal 1 ayat 16 disebutkan bahwa belanja daerah adalah kewajiban pemerintah daerah yang diakui sebagai pengurang nilai kekayaan bersih. Selanjutnya dalam Peraturan Pemerintah Nomor 58 Tahun 2005 pasal 20 ayat 3 menyebutkan bahwa Belanja Daerah seperti dimaksud pada ayat 1 huruf (a) meliputi semua pengeluaran dari rekening kas umum daerah yang mengurangi ekuitas dana lancar, yang merupakan kewajiban daerah dalam satu tahun anggaran yang tidak akan diperoleh pembayarannya kembali oleh daerah.

\section{Belanja Langsung}

Menurut Peraturan Menteri Dalam Negeri No. 13 Tahun 2006 Pasal 36 tentang Pedoman Pengelolaan Keuangan Daerah, belanja langsung merupakan belanja yang dianggarkan 
terkait secara langsung dengan pelaksanaan program dan kegiatan. Belanja langsung adalah terdiri dari:

1. Belanja Pegawai.

Belanja pegawai adalah belanja kompensasi, baik dalam bentuk uang maupun barang yang ditetapkan berdasarkan peraturan perundang- undangan yang diberikan kepada pejabat negara, Pegawai Negeri Sipil (PNS), dan pegawai yang dipekerjakan oleh pemerintah yang belum berstatus PNS sebagai imbalan atas pekerjaan yang telah dilaksanakan dimana pekerjaan tersebut yang berkaitan dengan pembentukan modal.

2. Belanja Barang dan Jasa.

Belanja barang dan jasa adalah pengeluaran untuk menampung pembelian barang dan jasa yang habis pakai untuk memproduksi barang dan jasa yang dipasarkan maupun tidak dipasarkan, dan pengadaan barang yang dimaksudkan untuk diserahkan atau dijual kepada masyarakat dan belanja perjalanan.

3. Belanja Modal.

Belanja modal adalah pengeluaran anggaran untuk perolehan aktiva tetap dan aset lainnya yang memberi manfaat lebih dari satu periode akuntansi. Untuk mengetahui apakah suatu belanja dapat dimasukkan sebagai belanja modal atau tidak, maka perlu diketahui definisi aset tetap atau aset lainnya dan kriteria kapitalisasi aset tetap.

\section{Belanja Tidak Langsung}

Menurut Peraturan Menteri Dalam Negeri No. 13 Tahun 2006 Pasal 36 tentang Pedoman Pengelolaan Keuangan Daerah, belanja tidak langsung atau BTL merupakan belanja yang tidak dipengaruhi secara langsung oleh adanya program atau kegiatan. Jenis belanja tidak langsung dapat berupa belanja pegawai/personalia, belanja tidak terduga, belanja hibah dan belanja bantuan sosial. Keberadaan belanja tidak langsung bukan merupakan konsekuensi dan atau tiada suatu program atau kegiatan, belanja tidak langsung digunakan secara periodik dalam koordinasi penyelenggaraan kewenangan pemerintahan daerah yang bersifat umum. Belanja tidak langsung pada dasarnya merupakan belanja yang digunakan secara bersama-sama untuk melaksanakan seluruh program atau kegiatan unit kerja. Oleh karena itu dalam perhitungan Standar Alokasi Belanja (SAB), anggaran belanja tidak langsung dalam satu tahun anggaran harus dialokasikan ke setiap program atau kegiatan yang akan dilaksanakan dalam tahun anggaran yang bersangkutan.

Program atau kegiatan-kegiatan yang memperoleh alokasi belanja tidak langsung adalah program atau kegiatan non investasi, program atau kegiatan investasi yang menambahkan aset daerah tidak menerima alokasi anggaran tahunan belanja tidak langsung, karena output program atau kegiatan investasi adalah merupakan aset daerah yang dimanfaatkan lebih satu tahun anggaran, anggaran belanja tidak langsung hanya digunakan untuk satu tahun anggaran seperti halnya output program atau kegiatan non investasi.

\section{Penelitian Terdahulu}

Beberapa hasil penelitian sebelumnya yang berkaitan dengan penelitian ini adalah sebagai berikut.

Sumarni (2008) melakukan penelitian dengan topik pengaruh Pendapatan Asli Daerah, Dana Alokasi Umum dan Dana Alokasi Khusus terhadap Belanja Modal Kabupaten/Kota Yogyakarta Tahun 20022007. Hasil penelitiannya menunjukan PAD dan DAK memiliki pengaruh positif signifikan terhada Belanja Modal, sementara DAU tidak berpengaruh signifikan terhada Belanja Modal.

Masdjojo dan Sukartono (2009) melakukan penelitian dengan toik pengaruh Pendapatan Asli Daerah dan Dana Perimbangan terhadap Belanja Daerah Kabupaten/Kota Di Jawa Tengah Tahun 2006-2008. Hasil penelitiannya menunjukan PAD, DAU dan Dana Bagi Hasil memiliki pengaruh positif signifikan terhada Belanja Daerah, sementara DAK tidak berpengaruh signifikan terhada Belanja Daerah.

Widjajakosoema (2011) melakukan penelitian dengan topik pengaruh Pendapatan Asli Daerah (PAD) terhadap Belanja Daerah Pemerintah Kota Kediri periode 2005-2009. 
Hasil penelitian menunjukan bahwa PAD berpengaruh positif dan signifikan terhadap Belanja Daerah pada Pemerintah Kota Kediri.

\section{Kerangka Pemikiran}

Hubungan Pendapatan Asli Daerah terhadap Belanja Daerah

Daerah yang ditunjang dengan sarana dan prasarana memadai akan berpengaruh pada tingkat produktivitas masyarakatnya dan akan menarik investor untuk menanamkan modalnya di daerah tersebut yang pada akhirnya akan menambah pendapatan asli daerah (Mardiasmo, 2002). Peningkatan PAD diharapkan mampu memberikan efek yang signifikan terhadap pengalokasian anggaran belanja daerah oleh pemerintah.

\section{Hubungan Dana Alokasi Khusus terhadap Belanja Daerah}

Diterapkannya desentralisasi fiskal, pemerintah pusat mengharapkan daerah dapat mengelola sumber daya yang dimiliki sehingga tidak hanya mengandalkan DAK. Di beberapa daerah peran DAK sangat signifikan karena karena kebijakan belanja daerah lebih di dominasi oleh jumlah DAK dan DAU daripada PAD (Mardiasmo, 2002). Setiap transfer DAK yang diterima daerah akan ditunjukkan untuk belanja pemerintah daerah, maka tidak jarang apabila pemerintah daerah menetapkan rencana daerah secara pesimis dan rencana belanja cenderung optimis supaya transfer DAK yang diterima daerah lebih besar.

Berdasarkan tinjauan pustaka dari hasil penelitian sebelumnya, maka bisa dinyatakan skema kerangka pemikiran penelitian ini seperti terlihat pada Gambar 1.

\section{Hipotesis Penelitian}

Hipotesis adalah pernyataan hubungan antara variabel sebagaimana dirumuskan dalam hipotesis hanya merupakan dugaan sementara atas suatu masalah yang didasarkan pada hubungan yang telah dijelaskan dalam kerangka teori yang digunakan untuk menjelaskan masalah penelitian (Gujarati, 2003:160). Berdasarkan pemikiran yang telah dijelaskan sebelumnya maka hipotesis dalam penelitian ini adalah:

H1 : Pendapatan Asli Daerah dan Dana Alokasi Khusus secara simultan berpengaruh secara simultan terhadap belanja daerah pada kota Banda Aceh periode 2010-2015.

H2 : Pendapatan Asli Daerah secara parsial berpengaruh terhadap belanja daerah pada kota Banda Aceh periode 20102015.

H3 : Dana Alokasi Khusus secara parsial berpengaruh terhadap belanja daerah pada di kota Banda Aceh periode 20102015.

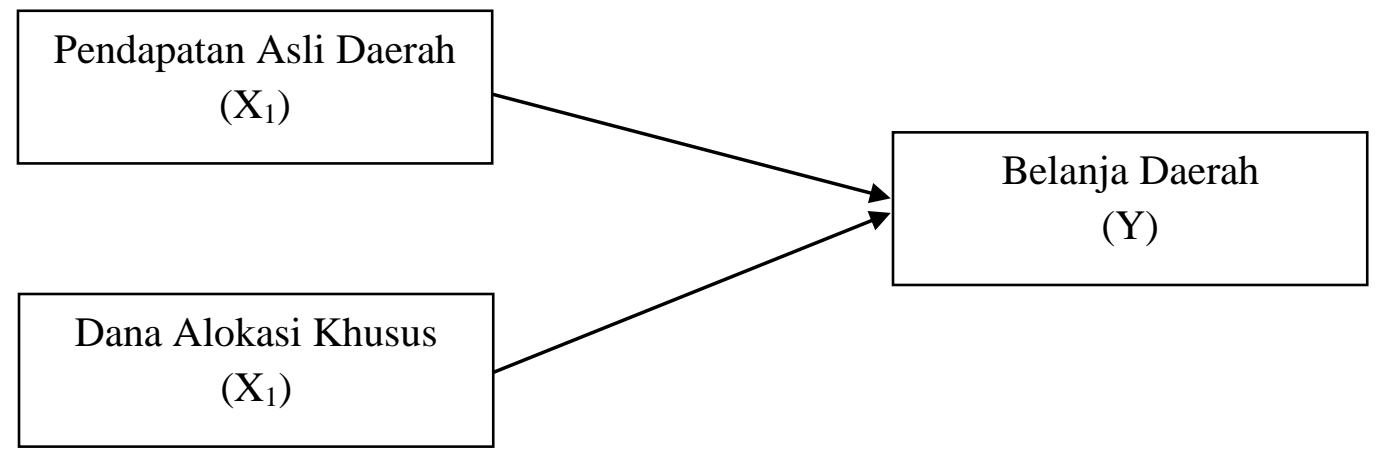

\section{Gambar 1. Kerangka Pemikiran}

\section{METODE PENELITIAN}

\section{Lokasi dan Objek Penelitian}

Lokasi dari penelitian ini adalah dilakukan di Dinas Pengelolaan Keuangan dan Aset Daerah (DPKAD) Kota Banda Aceh yang beralamat di JL. Tgk. Abu Lam U No. 07. Banda Aceh. Objek penelitian dalam penelitian ini yaitu Kota Banda Aceh dengan periode penelitian selama tahun 2010 sampai dengan 2015. 


\section{Populasi dan Sampel}

Populasi adalah wilayah generalisasi yang terdiri dan objek yang mempunyai kualitas dan karakteristik tertentu yang ditetapkan oleh peneliti untuk dipelajari dan kemudian ditarik kesimpulan (Sugiyono, 2012:80). Sampel adalah perwakilan dari populasi yang hasilnya mewakili keseluruhan gejala yang diamati. (Sugiyono, 2012:81).

Dalam penelitian ini, sampelnya adalah populasi tersebut, jadi populasi ini merupakan sampel penelitian. Data yang dianalisis dalam penulisan ini adalah data sekunder dengan metode sensus yang bersumber dari dokumen Laporan Realisasi APBD Kabupaten/Kota Banda Aceh yang diperoleh dari DPKAD Kota Banda Aceh dari laporan realisasi APBD ini diperoleh data mengenai jumlah realisasi Belanja Daerah, Pendapatan Asli Daerah (PAD) dan Dana Alokasi Khusus (DAK) tahun 2010-2015.

\section{Jenis dan Sumber Data}

Data yang digunakan dalam penelitian ini adalah data sekunder. Data sekunder adalah data yang telah ada dan tidak perlu dikumpulkan sendiri oleh peneliti (Gujarati, 2003:60). Data yang dianalisis dalam penelitian ini adalah data sekunder yang bersumber dari dokumen Laporan Realisasi APBD Kabupaten/Kota Banda Aceh yang diperoleh dari DPKAD Banda Aceh Dari laporan Realisasi APBD ini diperoleh data mengenai jumlah realisasi Belanja Daerah, Pendapatan Asli Daerah (PAD) dan Dana Alokasi Khusus (DAK).

Teknik pengumpulan data yang dilakukan adalah studi dokumentasi, yaitu dengan mencari data-data sekunder yang diperlukan dan yang berhubungan dengan masalah yang akan dibahas, serta dokumen lain yang berhubungan dengan masalah yang diteliti.

\section{Metode Analisis Data}

Metode analisis yang digunakan adalah regresi linier berganda. Pengertian regresi linear berganda adalah alat statistik yang digunakan untuk mengetahui pengaruh antara satu atau beberapa variabel terhadap satu buah variabel, variabel yang mempengaruhi sering disebut variabel independen dan dependen, yang bertujuan untuk menguji dan menganalisis, baik secara simultan maupun secara parsial (Gujarati, 2003:630).

Pengaruh pendapatan asli daerah dan dana alokasi khusus terhadap belanja daerah pada kota Banda Aceh yang diolah dengan program Statistical package for Social Science (SPSS). Persamaan regresi dalam penelitian ini adalah sebagai berikut:

$$
\mathrm{Y}=\alpha+\beta_{1} \mathrm{X}_{1}+\beta_{2} \mathrm{X}_{2}+\varepsilon
$$

Keterangan:

Y : Belanja Daerah

$\alpha$ : Konstanta

$\beta_{1}$ : Koefisien regresi Pendapatan Asli Daerah

$\beta_{2}$ : Koefisien regresi Dana Alokasi Khusus

$\mathrm{X}_{1}$ : Pendapatan Asli Daerah

$\mathrm{X}_{2}$ : Dana Alokasi Khusus

$\varepsilon \quad:$ Epsilon

\section{Pengujian Hipotesis}

Untuk menguji pengaruh pendapatan asli daerah dan dana alokasi khusus terhadap belanja daerah dalam penelitian ini dilakukan dengan cara sebagai berikut:

1. Uji secara Simultan (Uji F), menggunakan kriteria:

$\mathrm{H}_{0} 1$ : Jika $\beta_{1}=\beta_{2}=0$; maka $\mathrm{H}_{\mathrm{o}}$ diterima, $\mathrm{H}_{\mathrm{a}}$ ditolak. Artinya Pendapatan Asli Daerah dan Dana Alokasi Khusus secara simultan tidak berpengaruh terhadap belanja daerah pada Kota Banda Aceh 2010-2015.

$\mathrm{H}_{\mathrm{a}} 1$ : Jika $\beta_{1}=\beta_{2} \neq 0$; maka $\mathrm{H}_{\mathrm{o}}$ ditolak, $\mathrm{H}_{\mathrm{a}}$ diterima. Artinya Pendapatan Asli Daerah dan Dana Alokasi Khusus secara simultan berpengaruh terhadap belanja daerah pada Kota Banda Aceh 2010-2015.

2. Uji secara Parsial (Uji t), menggunakan kriteria:

$\mathrm{H}_{0} 2$ : Jika $\beta_{1}=0$; maka $\mathrm{H}_{\mathrm{o}}$ diterima, $\mathrm{H}_{\mathrm{a}}$ ditolak. Artinya Pendapatan Asli Daerah secara parsial tidak berpengaruh terhadap belanja 
daerah pada Kota Banda Aceh 2010-2015.

$\mathrm{H}_{\mathrm{a}} 2$ : Jika $\beta_{1} \neq 0$; maka $\mathrm{H}_{\mathrm{o}}$ ditolak, $\mathrm{H}_{\mathrm{a}}$ diterima. Artinya Pendapatan Asli Daerah secara parsial berpengaruh terhadap belanja daerah pada Kota Banda Aceh 2010-2015.

$\mathrm{H}_{0} 3$ : Jika $\beta_{2}=0$; maka $\mathrm{H}_{\mathrm{o}}$ diterima, $\mathrm{H}_{\mathrm{a}}$ ditolak. Artinya Dana Alokasi Khusus secara parsial tidak berpengaruh terhadap belanja daerah pada Kota Banda Aceh 2010-2015.

$\mathrm{H}_{\mathrm{a}} 3$ : Jika $\beta_{2} \neq 0$; maka $\mathrm{H}_{\mathrm{o}}$ ditolak, $\mathrm{H}_{\mathrm{a}}$ diterima. Artinya Dana Alokasi Khusus secara parsial berpengaruh terhadap belanja daerah pada Kota Banda Aceh 2010-2015.

\section{Uji Asumsi Klasik}

Sebelum dilakukan pengujian pengaruh pendapatan asli daerah dan dana alokasi khusus terhadap belanja daerah secara simultan menggunakan analisis regresi berganda, maka dilakukan pengujian asumsi klasik terlebih dahulu untuk melihat apakah model penelitian data yang digunakan berdistribusi normal atau tidak, apakah terdapat gejala autokorelasi atau tidak.

\section{Uji Normalitas}

Uji Normalitas merupakan suatu pengujian untuk mengetahui apakah dalam model regresi mempunyai ditribusi normal atau tidak. Hal tersebut penting karena bila data setiap variabel tidak normal, maka pengujian hipotesis tidak bisa menggunakan statistik parametrik (Sugiyono, 2012:239).

Menurut Uyanto (2010:40), uji normalitas data menggunakan statistik SPSS Kolmogrov-Smirnov dengan dasar pengambilan keputusan bisa dilakukan probabilitas (asymptotic significancy) yaitu:

- Jika probabilitas $\mathrm{x}, \mathrm{y}>0,05$ maka distribusi dari populasi adalah normal.

- Jika probabilitas $\mathrm{x}, \mathrm{y}<0,05$ maka distribusi dari populasi tidak normal.

\section{Uji Multikolinearitas}

Multikolinearitas merupakan situasi dimana beberapa atau semua variabel bebas berkolerasi kuat (Uyanto, 2010:40). Apabila terdapat korelasi yang kuat diantara sesama variabel independen maka konsekuensinya adalah:

- Koefisien-koefisien regresi menjadi tidak dapat ditaksir.

- Nilai standar error setiap koefisien regresi menjadi tidak terhingga. Dengan demikian berarti semakin besar korelasi diantara sesama variabel independen, maka tingkat kesalahan dari koefisien regresi semakin besar yang mengakibatkan standar errornya semakin besar pula.

\section{Uji Heterokedastisitas}

Menurut Ghozali (2007:107), uji heterokedastisitas bertujuan menguji apakan dalam model regresi terjadi ketidaksamaan varians dari residual atau pengamatan ke pengamatan yang lain. Jika varians dari residual suatu pengamatan ke pengamatan lain tetap, maka disebut heterokedastisitas. Model yang baik adalah yang mengalami homoskesdatisitas ataupun tidak mengalami heteroskedastisitas, karena model ini menghimpun data yang mewakili berbagai ukuran.

\section{Uji Autokorelasi}

Uji autokorelasi dimaksudkan untuk menguji suatu keadaan dimana pada model regresi terdapat hubungan antara variabel; atau dengan kata lain, terdapat korelasi antara residual pada periode $t$ dengan residual pada periode sebelumnya $(t-1)$ (Ghozali, 2007: 122). Model regresi yang baik adalah yang tidak terdapat masalah autokorelasi. Akibat dari adanya autokorelasi dalam model regresi, koefisien regresi yang diperoleh menjadi tidak efisien, artinya tingkat kesalahannya menjadi sangat besar dan koefisien regresi menjadi tidak stabil.

\section{Definisi Operasional Variabel Penelitian}

Penelitian ini terdiri dari tiga variabel. yaitu dua variabel independen (X) yaitu Pendapatan Asli Daerah (X1) dan Dana Alokasi Khusus (X2), dan satu variabel dependen (Y) yaitu Belanja Daerah. Definisi Operasional dari masing-masing variabel penelitian ini dinyatakan dalam Tabel 1 . 
Tabel 1. Definisi dan Operasionalisasi variabel

\begin{tabular}{cclcc}
\hline No & \multicolumn{1}{c}{ Variabel } & \multicolumn{1}{c}{ Definisi } & Indikator & Skala \\
\hline 1. & $\begin{array}{l}\text { Pendapatan Asli } \\
\text { Daerah }\end{array}$ & $\begin{array}{l}\text { Semua penerimaan daerah yang } \\
\text { berasal dari sumber ekonomi asli } \\
\text { daerah, seperti pajak, retribusi, } \\
\text { hasil pengelolaan kekayaan } \\
\text { daerah yang dipisahkan dan lain- } \\
\text { lain }\end{array}$ & $\begin{array}{c}\text { PAD }= \\
\text { Pajak daerah + retribusi daerah } \\
\text { + hasil pengelolaan kekayaan } \\
\text { daerah yang dipisahkan + lain- } \\
\text { lain pendapatan yang sah }\end{array}$ & Nominal \\
& & $\begin{array}{l}\text { DAK dialokasikan dengan } \\
\text { tujuan kemampuan keuangan } \\
\text { antar daerah untuk mendanai } \\
\text { kebutuhan khusus daerah dalam } \\
\text { pelaksanaan desentralisasi. }\end{array}$ & $\begin{array}{c}\text { Dana yang ditransfer } \\
\text { pemerintah pusat kepada } \\
\text { perintah daerah yang } \\
\text { bersumber APBN }\end{array}$ & Nominal \\
\hline Khusus & Dana Alokasi & $\begin{array}{l}\text { Semua pengeluaran kas daerah } \\
\text { dalam periode tahun anggaran } \\
\text { tertentu yang menjadi beban } \\
\text { daerah (kepmendagri No. 29 } \\
\text { Tahun 2002) }\end{array}$ & $\begin{array}{c}\text { Belanja Daerah }= \\
\text { Belanja Langsung + Belanja } \\
\text { tidak Langsung }\end{array}$ & \\
\hline 3. & Belanja Daerah \\
(Y) & & &
\end{tabular}

Sumber: Diolah peneliti, 2017.

\section{HASIL ANALISIS}

\section{Sejarah Kota Banda Aceh}

Kota Banda Aceh adalah salah satu kota yang berada di Aceh dan menjadi ibukota Provinsi Aceh, Indonesia. Sebagai pusat pemerintahan, Banda Aceh menjadi pusat kegiatan ekonomi, politik, sosial dan budaya. Kota Banda Aceh juga merupakan kota Islam yang paling tua di Asia Tenggara, di mana Kota Banda Aceh merupakan ibu kota dari Kesultanan Aceh. Banda Aceh sebagai ibu kota Kesultanan Aceh Darussalam berdiri pada abad ke-14. Kesultanan Aceh Darussalam dibangun di atas puing-puing kerajaan-kerajaan Hindu dan Budha yang pernah ada sebelumnya, seperti Kerajaan Indra Purba, Kerajaan Indra Purwa, Kerajaan Indra Patra, dan Kerajaan Indrapura (Indrapuri). Dari batu nisan Sultan Firman Syah, salah seorang sultan yang pernah memerintah Kesultanan Aceh, diperoleh keterangan bahwa Kesultanan Aceh beribukota di Kutaraja (Banda Aceh).

Kemunculan dari Kesultanan Aceh Darussalam yang beribukota di Banda Aceh tidak lepas dari eksistensi Kerajaan Islam Lamuri. Pada akhir abad ke-15, dengan terjalinnya suatu hubungan baik dengan kerajaan tetangganya, maka pusat singgasana
Kerajaan Lamuri dipindahkan ke Meukuta Alam. Lokasi istana Meukuta Alam berada di wilayah Banda Aceh. Sultan Ali Mughayat Syah memerintah Kesultanan Aceh Darussalam yang beribukota di Banda Aceh, hanya selama 10 tahun. Menurut prasasti yang ditemukan dari batu nisan Sultan Ali Mughayat Syah, pemimpin pertama Kesultanan Aceh Darussalam ini meninggal dunia pada 12 Dzulhijah Tahun 936 Hijriah atau bertepatan dengan tanggal 7 Agustus 1530 Masehi. Kendati masa pemerintahan Sultan Mughayat Syah relatif singkat, namun ia berhasil membangun Banda Aceh sebagai pusat peradaban Islam di Asia Tenggara. Pada masa ini, Banda Aceh telah berevolusi menjadi salah satu kota pusat pertahanan yang ikut mengamankan jalur perdagangan maritim dan lalu lintas jemaah haji dari perompakan yang dilakukan armada Portugis.

Pada masa Sultan Iskandar Muda, Banda Aceh tumbuh kembali sebagai pusat perdagangan maritim, khususnya untuk komoditas lada yang saat itu sangat tinggi permintaannya dari Eropa. Iskandar Muda menjadikan Banda Aceh sebagai taman dunia, yang dimulai dari komplek istana. Komplek istana Kesultanan Aceh juga dinamai Darud Dunya (Taman Dunia). Pada masa agresi 
Belanda yang kedua, terjadi evakuasi besarbesaran pasukan Aceh keluar dari Banda Aceh yang kemudian dirayakan oleh Van Swieten dengan memproklamasikan jatuhnya kesultanan Aceh dan mengubah nama Banda Aceh menjadi Kuta Raja. Setelah masuk ke dalam pangkuan Pemerintah Republik Indonesia baru sejak 28 Desember 1962 nama kota ini kembali diganti menjadi Banda Aceh berdasarkan Keputusan Menteri Pemerintahan Umum dan Otonomi Daerah bertanggal 9 Mei 1963 No. Des 52/1/43-43.

\section{Deskripsi Variabel Penelitian}

Penelitian ini dilakukan berdasarkan hipotesis yang telah dirumuskan variabel yang digunakan meliputi variabel belanja daerah sebagai variabel dependen, Pendapatan Asli Daerah (PAD) dan Dana Alokasi Khusus (DAK) sebagai variabel independen. Periode tahun yang digunakan dalam penelitian ini yaitu selama 6 tahun yaitu tahun 2010 sampai dengan tahun 2015 dengan sampel yang digunakan yaitu laporan keuangan Pemerintah Kota Banda Aceh.

Analisis data dan pengujian hipotesis menggunakan metode regresi linier berganda. Data yang digunakan untuk mengukur nilai variabel baik variabel dependen maupun variabel independen adalah data laporan keuangan Pemerintah Kota Banda Aceh periode 2010-2015.

\section{Pendapatan Asli Daerah}

Pendapatan Asli Daerah (PAD) dalam penelitian ini dapat dilihat pada Tabel 2 . Berdasarkan Tabel 2. diperoleh total PAD Pemerintah Kota Banda Aceh periode 20102015 sebesar Rp. 692.242.579.142.000, ratarata PAD periode 2010-2015 adalah sebesar Rp. 115.373.763.190.330, PAD terendah yaitu pada tahun 2010 dengan nilai sebesar Rp. 60.558.012.773.000, selama periode penelitian. PAD tertinggi yaitu pada tahun 2015 dengan nilai Rp. 196.500.996.271.000, selama periode penelitian.

\section{Dana Alokasi Khusus}

Dana Alokasi Khusus (DAK) dalam penelitian ini dapat dilihat pada Tabel 3 . Berdasarkan Tabel 3 diperoleh total DAK Pemerintah Kota Banda Aceh periode 2010-2015 sebesar Rp. 190,477,140,000, rata-rata DAK periode 2010-2015 sebesar Rp. $31,746,190,000$, DAK terendah yaitu pada tahun 2010 dengan nilai Rp. 21.351.600.000, selama periode penelitian. DAK tertinggi pada tahun 2015 dengan nilai sebesar Rp. 42.758.540.000, selama periode penelitian.

Tabel 2. PAD Pemerintah Kota Banda Aceh Periode 2010-2015 (dalam Rp)

\begin{tabular}{lcc}
\hline \multicolumn{3}{c}{ Pendapatan Asli Daerah (PAD) } \\
\hline Tahun & PAD (Rp) \\
& 2010 & 60.558 .012 .773 .00 \\
& 2011 & 80.242 .201 .217 .00 \\
& 2012 & 91.189 .567 .799 .00 \\
& 2013 & 107.777 .767 .158 .00 \\
& 2014 & 155.974 .033 .924 .00 \\
Total & 2015 & 196.500 .996 .271 .00 \\
Rata-Rata & & 692.242 .579 .142 .00 \\
NILAI MINIMUM & 115.373 .763 .190 .33 \\
NILAI MAKSIMUM & 60.558 .012 .773 .00 \\
\hline
\end{tabular}

Sumber: DPKAD Kota Banda Aceh 
Tabel 3. DAK Pemerintah Kota Banda Aceh Periode 2010-2015 (dalam Rp)

\begin{tabular}{lcc}
\hline \multicolumn{3}{c}{ Dana Alokasi Khusus (DAK) } \\
\hline Tahun & DAK $(\mathrm{Rp})$ \\
\hline 2010 & 21.351 .600 .000 .00 \\
2011 & 29.637 .200 .000 .00 \\
& 2012 & 26.893 .570 .000 .00 \\
& 2013 & 31.003 .110 .000 .00 \\
& 2014 & 38.833 .120 .000 .00 \\
& 2015 & 42.758 .540 .000 .00 \\
\hline Total & & 190.477 .140 .000 .00 \\
Rata-Rata & & 31.746 .190 .000 .00 \\
NILAI MINIMUM & 21.351 .600 .000 .00 \\
NILAI MAKSIMUM & 42.758 .540 .000 .00 \\
\hline
\end{tabular}

Sumber: DPKAD Kota Banda Aceh

Tabel 4. Belanja Daerah Pemerintah Kota Banda Aceh Periode 2010-2015 (dalam Rp)

\begin{tabular}{lcc}
\hline \multicolumn{2}{c}{ Belanja Daerah } \\
\hline Tahun & Belanja Daerah (Rp) \\
& 2010 & 601.093 .380 .933 .00 \\
& 2011 & 750.476 .593 .750 .00 \\
& 2012 & 812.298 .188 .644 .00 \\
& 2013 & 985.975 .685 .419 .00 \\
& 2014 & 1.194 .481 .738 .323 .00 \\
Total & 2015 & 1.290 .865 .471 .460 .00 \\
Rata-Rata & & 5.635 .191 .058 .529 .00 \\
NILAI MINIMUM & 939.198 .509 .754 .83 \\
NILAI MAKSIMUM & 601.093 .380 .933 .00 \\
\hline
\end{tabular}

Sumber: DPKAD Kota Banda Aceh

\section{Belanja Daerah}

Belanja Daerah dalam penelitian ini dapat dilihat pada Tabel 4. Berdasarkan Tabel 4. diperoleh total belanja daerah Pemerintah Kota Banda Aceh periode 2010-2015 adalah sebesar Rp. 5.635.191.058.529.000, rata-rata belanja daerah periode 2010-2015 adalah sebesar Rp. 939.198.509.754.83; nilai belanja daerah terendah yaitu pada tahun 2010 sebesar Rp. 601.093.380.933.000 selama periode penelitian. Belanja daerah tertinggi yaitu pada tahun 2015 dengan nilai sebesar
Rp. 1.290.865.471.460.000 selama periode penelitian.

\section{Deskripsi Statistik}

Deskripsi penelitian memberikan gambaran mengenai karakteristik variabelvariabel penelitian yang diamati. Deskripsi data atas variabel yang digunakan dalam penelitian ini dapat dilihat pada Tabel 5.

Berdasarkan Tabel 5 belanja daerah secara keseluruhan memiliki nilai minimum sebesar Rp. 601.093.380.933, nilai maksimum sebesar Rp. 1.290.865.471.460. Nilai mean 
sebesar Rp. 93.919.850.975,483, nilai standar deviasi sebesar Rp. 2.672.309.151,255, artinya jumlah rata-rata variabilitas belanja daerah selama periode penelitian adalah sebesar Rp. 2.672.309.151,255.

Pendapatan Asli Daerah secara keseluruhan memiliki nilai minimum sebesar Rp. 60.558.012.773, nilai maksimum sebesar Rp. 196.500.996.271. Nilai mean sebesar Rp. 11.537.376.319,033, nilai standar deviasi sebesar Rp. 5.120.854.915,192, yang berarti jumlah rata-rata variabilitas pendapatan asli daerah selama periode penelitian adalah sebesar Rp. 5.120.854.915,192.

Dana Alokasi Khusus secara keseluruhan memiliki nilai minimum sebesar $\mathrm{Rp}$. 21.351.600.000, nilai maksimum sebesar Rp. 42.758.540.000. Nilai mean sebesar Rp. 31.746.190.000.000, nilai standar deviasi sebesar Rp. 7.849.737.042.556, yang berarti jumlah rata-rata variabilitas dana alokasi khusus selama periode penelitian sebesar Rp. 7.849.737.042.556.

\section{Tabel 5. Deskriptif Data Statistik atas Variabel}

\begin{tabular}{lccccc}
\hline & N & Minimum & Maximum & Mean & Std. Deviation \\
\hline Belanja Daerah & 6 & 601093380933 & 1290865471460 & 939198509754,83 & 2672309151,255 \\
PAD & 6 & 60558012773 & 196500996271 & 115373763190,33 & 5120854915,192 \\
DAK & 6 & 21351600000 & 42758540000 & 317461900000,00 & 7849737042,556 \\
\hline Valid N (listwise) & 6 & & & & \\
\hline
\end{tabular}

Sumber: Data sekunder diolah, 2017.

Tabel 6. Hasil Uji Normalitas dengan Kolgomorov-Smirnov

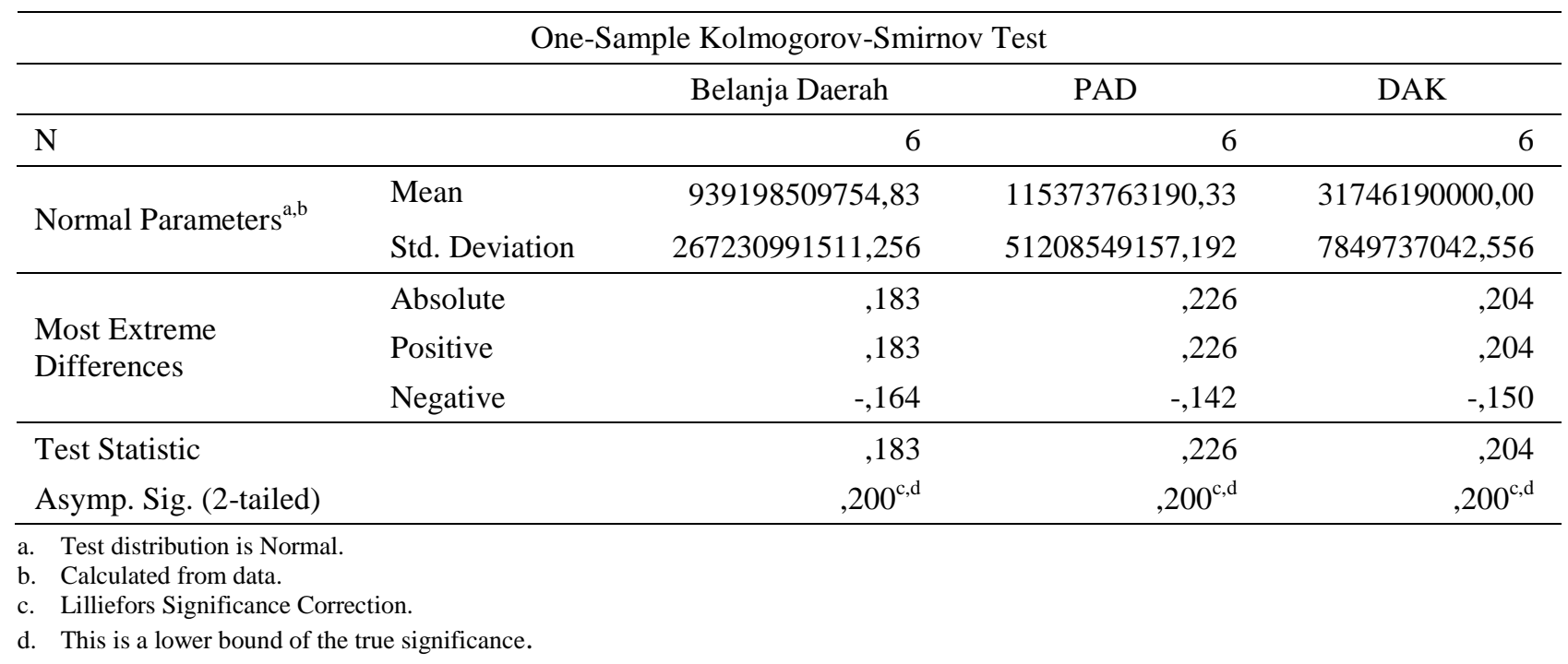

Sumber: Data sekunder diolah, 2017.

\section{Uji Asumsi Klasik}

Sebelum dilakukan pengujian regresi linier berganda terhadap hipotesis penelitian, maka terlebih dahulu perlu dilakukan suatu pengujian untuk mengetahui ada tidaknya pelanggaran terhadap asumsi-asumsi klasik. Hasil pengujian hipotesis yang baik adalah pengujian yang tidak melanggar asumsiasumsi klasik yang mendasari model regresi linier berganda. Asumsi-asumsi klasik dalam penelitian ini meliputi uji normalitas, uji multikolinieritas, uji heteroskedastisitas dan uji autokorelasi.

\section{Uji Normalitas}

Pengujian normalitas bertujuan untuk menguji apakah dalam model regresi antara variabel dependen dan variabel independen keduanya mempunyai distribusi normal ataukah tidak. Model regresi yang baik adalah yang memiliki dsitribusi normal atau mendekati normal (Santoso, 2000:212), yang 
dapat dilihat dengan menggunakan nilai signifikansi residual dari uji Kolmogorov Smirnov (normal bila > 0.05) atau dengan menggunakan Normal Probability Plot, jika distribusi data normal, maka garis yang menggambarkan data sesungguhnya akan mengikuti garis diagonal dan jika data menyebar jauh dari garis diagonal, maka model regresi tidak memenuhi asumsi normalitas.

Hasil perhitungan untuk uji normalitas residual dari persamaan taksiran yang diperoleh menggunakan SPSS versi 22 adalah seperti terlihat pada Tabel 6. Berdasarkan Tabel 6 untuk menentukan data dengan menggunakan uji statistik non-parametrik Kolmogorov Smirnov, nilai signifikasi harus diatas 0,05 atau 5\% (Ghozali, 2009:109). Pengujian atas normalitas residual dengan menggunakan uji Kolmogorov-Smirnov, maka diperoleh belanja daerah mempunyai nilai Kolmogorov-Smirnov sebesar 183, PAD memiliki nilai Kolmogorov-Smirnov sebesar 226, DAK mempunyai nilai KolmogorovSmirnov sebesar 204 dengan nilai signifikansi sebesar 0,200. Hal ini berarti Ho diterima yang berarti data residual terdistribusi normal.

Metode kedua yang bisa digunakan untuk uji normalitas adalah dengan Normal Probability Plot yang membandingkan distribusi kumulatif dari distribusi normal. Jika distribusi data residual normal, maka garis yang akan menggambarkan data sesungguhnya akan mengikuti garis diagonal. Uji normalitas data dengan Normal Probability Plot terlihat dalam Gambar 2. Dari Gambar 2 tersebut terlihat Normal Probability Plot di atas menunjukkan bahwa data menyebar disekitar garis diagonal dan mengikuti arah garis diagonal, dan menunjukkan pola distribusi normal, sehingga dapat disimpulkan bahwa asumsi normalitas telah terpenuhi.

\section{Uji Multikolinearitas}

Uji multikolinearitas digunakan untuk mendeteksi ada tidaknya hubungan linier di antara variabel bebas dalam model regresi. Pengujian ada atau tidaknya multikolinearitas dapat dilakukan menggunakan perhitungan Tolerance (TOL) dan metode VIF (Variance Inflation Factor). Hasil uji multikolinearitas dapat dilihat pada Tabel 7. Berdasarkan Tabel 7 tersebut maka bisa diketahui nilai Tolerance yang diperoleh mendekati 1 dan nilai VIF untuk masing-masing variabel penelitian ini kurang dari 10, sehingga dapat dinyatakan tidak terjadi gejala multikolinieritas pada variabel independen karena nilai VIF $<10$.

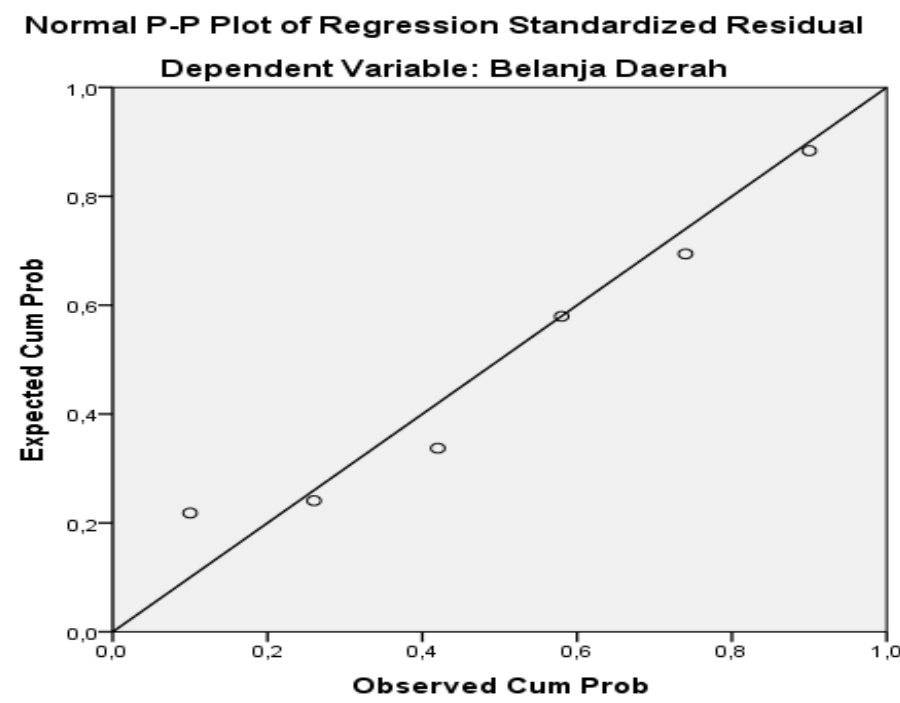

Sumber: Data sekunder diolah, 2017

Gambar 2. Hasil Uji Normalitas dengan Normal Probability Plot 


\section{Uji Heterokedastisitas}

Uji heterokedastisitas bertujuan untuk menguji apakah dalam model regresi terjadi ketidaksamaan varian dari residual satu pengamatan ke pengamatan yang lain. Pada suatu model regresi yang baik varians nilai residual dari pengamatan memiliki kondisi homokedastisitas atau tidak terjadi heterokedastisitas. Untuk mendeteksi ada atau tidaknya problem heteroskedastisitas pada peneltian ini digunakan scatter plot antara nilai prediksi variabel terikat dengan residualnya. Dasr pengambilan keputusannya adalah:

- Jika ada pola tertentu, seperti titik-titik yang ada membentuk pola tertentu yang teratur (bergelombang, melebar kemudian menyempit), maka mengindikasikan telah terjadi heterokedaktisitas.

- Jika ada pola yang jelas, seperti titik-titik menyebar di atas dan di bawah angka 0 pada sumbu Y, maka tidak terjadi heterokedaktisitas.

Ada atau tidaknya masalah heteroskedastisitas dalam penelitian ini dapat dideteksi dengan melihat sebaran titik-titik pada scatterplot dalam Gambar 3. Berdasarkan Gambar dari grafik scatterplot tersebut tidak menunjukkan pola atau bentuk tertentu, tampak titik menyebar secara acak serta data menyebar secara merata di atas sumbu $\mathrm{X}$ maupun di atas sumbu $\mathrm{Y}$, maka dapat disimpulkan tidak terjadi heteroskedastisitas pada model regresi linier penelitian ini.

\section{Tabel 7. Hasil Uji Multikolinieritas}

\begin{tabular}{clcc}
\multicolumn{5}{c}{ Coefficients $^{\mathrm{a}}$} \\
\hline \multicolumn{3}{c}{ Collinearity Statistics } \\
\hline Model & & Tolerance & VIF \\
\hline 1 & (Constant) &, 061 & 16,501 \\
& PAD &, 061 & 16,501 \\
& DAK & &
\end{tabular}

Sumber: Data sekunder diolah, 2017.

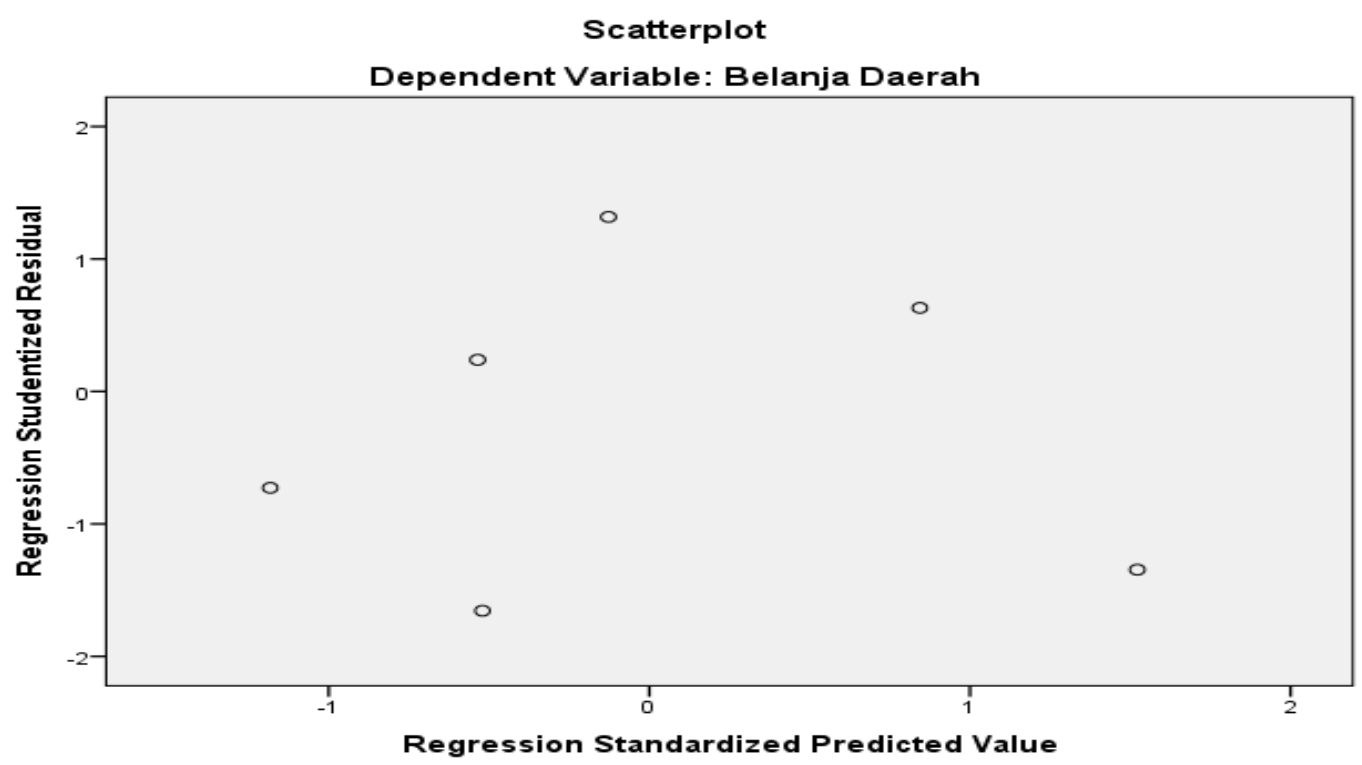

Sumber: Data sekunder diolah, 2017

Gambar 2. Hasil Uji Heterokedastisitas 


\section{Uji Autokolerasi}

Uji autokorelasi bertujuan menguji apakah dalam suatu model regresi linear ada korelasi antara kesalahan pengganggu pada periode $t$ dengan kesalahan pada periode $t-1$. Autokorelasi muncul karena observasi yang berurutan sepanjang waktu berkaitan satu sama lain. Masalah ini timbul karena residual (kesalahan pengganggu) tidak bebas dari satu observasi ke observasi lainnya. Model regresi yang baik adalah regresi yang bebas dari autokorelasi (Santoso, 2002:219). Pengujian penyimpangan autokorelasi dalam penelitian ini dengan menggunakan Durbin-Watson Test (DW- test).

Berdasarkan Tabel 8 dapat dilihat hasil uji Durbin-Watson sebesar 1,337; sedangkan dalam tabel DW untuk " $\mathrm{k}$ " $=2$ dan $\mathrm{N}=30$ besaran nilai DW-tabel: dl (batas luar) = 6718430,242 dan du (batas dalam) =0,937; $2-\mathrm{du}=0,962$ dan $2-\mathrm{dl}=0,981$. Karena itu, nilai DW 6718430,242 lebih besar dari batas (du) 0,937 dan DW kurang dari 2 0,962, maka dapat disimpulkan bahwa DW-test tidak dapat menolak Ho yang menyatakan bahwa tidak ada autokorelasi positif atau negatif atau dapat disimpulkan tidak terdapat autokorelasi.

\section{Regresi Linier Berganda}

Untuk menguji pengaruh antara variabel independen pendapatan asli daerah dan dana alokasi khusus dengan variabel dependen belanja daerah digunakan analisis regresi linier berganda dengan bantuan program SPSS versi 22 dan hasilnya seperti terlihat pada Tabel 9. Berdasarkan Tabel 9 maka dapat diformulakan persamaan regresi linier berganda dalam penelitian ini sebagai berikut:

$$
Y=15,221+3,064 X_{1}+13,656 X_{2}+\varepsilon
$$

Tabel 8. Hasil Uji Autokorelasi

\begin{tabular}{|c|c|c|c|c|c|}
\hline \multicolumn{6}{|c|}{ Model Summary $^{\mathrm{b}}$} \\
\hline Model & $\mathrm{R}$ & R Square & $\begin{array}{l}\text { Adjusted R } \\
\text { Square }\end{array}$ & $\begin{array}{l}\text { Std. Error of the } \\
\text { Estimate }\end{array}$ & $\begin{array}{l}\text { Durbin- } \\
\text { Watson }\end{array}$ \\
\hline 1 &, $981^{\mathrm{a}}$ & ,962 & ,937 & 6718430,242 & 1,337 \\
\hline
\end{tabular}

a. Predictors: (Constant), DAK, PAD

b. Dependent Variable: Belanja Daerah

Sumber: Data sekunder diolah, 2017.

Tabel 9. Hasil Analisis Regresi Berganda

Coefficients $^{\mathrm{a}}$

\begin{tabular}{|c|c|c|c|c|c|c|}
\hline \multirow[b]{2}{*}{ Model } & & \multicolumn{2}{|c|}{$\begin{array}{l}\text { Unstandardized } \\
\text { Coefficients }\end{array}$} & \multirow{2}{*}{$\begin{array}{c}\begin{array}{c}\text { Standardized } \\
\text { Coefficients }\end{array} \\
\text { Beta }\end{array}$} & \multirow[b]{2}{*}{$\mathrm{t}$} & \multirow[b]{2}{*}{ Sig. } \\
\hline & & $\mathrm{B}$ & Std. Error & & & \\
\hline \multirow[t]{3}{*}{1} & (Constant) & 15,221 & 23,854 & & ,638 & ,569 \\
\hline & PAD & 3,064 & 2,383 & ,587 & 1,285 & ,289 \\
\hline & DAK & 13,656 & 15,548 & ,401 & ,878 & ,444 \\
\hline
\end{tabular}

a. Dependent Variable: Belanja Daerah

Sumber: Data sekunder diolah, 2017.

Tabel 10. Hasil Koefisien Korelasi dan Determinasi

Model Summary ${ }^{\mathrm{b}}$

\begin{tabular}{|c|c|c|c|c|}
\hline Model & $\mathrm{R}$ & R Square & $\begin{array}{l}\text { Adjusted R } \\
\text { Square }\end{array}$ & $\begin{array}{l}\text { Std. Error of the } \\
\text { Estimate }\end{array}$ \\
\hline 1 &, $981^{\mathrm{a}}$ & ,962 & ,937 & 6718430,242 \\
\hline
\end{tabular}

a. Predictors: (Constant), DAK, PAD

Sumber: Data sekunder diolah, 2017. 


\section{Koefisien Korelasi dan Determinasi}

Untuk melihat hubungan dan pengaruh antara variabel independen (PAD dan DAK) terhadap variabel dependen (Belanja Daerah) berdasarkan korelasi dan determinasi dapat dilihat pada Tabel 10.

\section{Pengujian Hipotesis}

Berdasarkan hasil-hasil pengujian dan pembahasan yang telah diuraikan, maka dapat dilakukan pengujian hipotesis atas model dalam penelitian ini sebagai berikut.

1. Uji Secara Simultan (Uji F).

H1: $\beta_{1}=3,064$ dan $\beta_{2}=13,656$ maka $\beta_{1}=\beta_{2} \neq 0$. Dengan demikian dapat disimpulkan hipotesis nol $\left(\mathrm{H}_{0}\right)$ ditolak dan hipotesis alternatif $(\mathrm{Ha})$ diterima. Artinya bahwa Pendapatan Asli Daerah dan Dana Alokasi Khusus secara simultan memiliki pengaruh terhadap belanja daerah pada Kota Banda Aceh periode 2010-2015.

2. Uji Secara Parsial (Uji t).

H2: $\beta_{1}=3,064$ maka $\beta_{1} \neq 0$. Dengan demikian dapat disimpulkan hipotesis nol $\left(\mathrm{H}_{0}\right)$ ditolak dan hipotesis alternatif $(\mathrm{Ha})$ diterima. Artinya bahwa Pendapatan Asli Daerah berpengaruh positif terhadap belanja daerah pada Kota Banda Aceh periode 2010-2015.

H3: $\beta_{2}=13,656$ maka $\beta_{2} \neq 0$. Maka dapat disimpulkan hipotesis nol $\left(\mathrm{H}_{0}\right)$ ditolak dan hipotesis alternatif (Ha) diterima. Artinya bahwa Dana Alokasi Khusus berpengaruh positif terhadap belanja daerah pada Kota Banda Aceh periode 2010-2015.

\section{Pembahasan}

Berdasarkan hasil-hasil penelitian dan pengujian hipotesis menunjukkan bahwa Pendapatan Asli Daerah dan Dana Alokasi Khusus berpengaruh terhadap belanja daerah pada Kota Banda Aceh periode 2010-2015. Nilai konstanta sebesar 15,221, dan variabel Pendapatan Asli Daerah (PAD) berpengaruh positif terhadap belanja daerah koefisien $\beta_{1}$ sebesar 3,064, menunjukkan apabila terjadi peningkatan PAD sebesar satu satuan maka, akan mempengaruhi belanja daerah sebesar 3,064 atau meningkatkan belanja daerah sebesar 306,4\%. Dana Alokasi Khusus (DAK) berpengaruh pisitif terhadap belanja daerah koefisien $\beta_{2}$ sebesar 13,656, menunjukkan apabila terjadi peingkatan DAK sebesar satu satuan maka, akan mempengaruhi belanja daerah sebesar 13,656 atau meningkatkan belanja daerah sebesar 1365,6\%.

Nilai Koefisien korelasi (R) sebesar 0,981 menunjukan korelasi antara variabel dependen dengan variabel independen sebesar $98,1 \%$. Artinya variabel dependen memiliki hubungan yang relatif kuat dengan variabel independen. Nilai koefisien determinasi $\left(\mathrm{R}^{2}\right)$ sebesar 0,962 dapat diartikan bahwa 96,2\% Pendapatan Asli Daerah dan Dana Alokasi Khusus mempengaruhi belanja daerah; sedangkan sisanya sebesar 3,8\% dipengaruhi oleh variabel-variabel lain yang tidak dimasukkan dalam model penelitian ini.

Pendapatan Asli Daerah berpengaruh positif terhadap belanja daerah sesuai dengan hasil yang dilakukan dengan Masdjojo dan Sukartono (2009); sementara, Dana Alokasi Khusus berpengaruhi positif terhadap belanja modal sesuai dengan hasil penelitian yang dilakukan dengan Sumarni (2008).

\section{KESIMPULAN}

Berdasarkan hasil-hasil penelitian, maka dapat disimpulkan beberapa hal berikut:

1. Pendapatan Asli Daerah dan Dana Alokasi Khusus secara simultan berpengaruh terhadap Belanja Daerah pada Kota Banda Aceh periode 2010-2015.

2. Pendapatan Asli Daerah berpengaruh Positif terhadap Belanja Daerah pada kota Banda Aceh periode 2010-2015 dengan koefisien $\beta_{1}$ sebesar 306,4\%.

3. Dana Alokasi Khusus berpengaruh Positif terhadap Belanja Daerah pada kota Banda Aceh periode 2010-2015 dengan koefisien $\beta_{2}$ sebesar 1365,6\%.

4. Nilai $R$ diperoleh sebesar 0,981 menunjukkan bahwa korelasi antara variabel dependen dengan variabel independen sebesar $98,1 \%$. Hal ini berarti variabel dependen memiliki hubungan yang kuat dengan variabel independen.

5. Nilai $R^{2}$ diperoleh sebesar 0,962 artinya kemampuan variabel independen didalam 
menjelaskan variabel dependen sebesar 96,2\%; dan sisanya 3,8\% dijelaskan oleh variabel-variabel lain yang tidak dimasukkan dalam model penelitian ini.

Berdasarkan kesimpulan yang telah dinyatakan, maka disampaikan beberapa saran berikut.

1. Disarankan untuk penelitian selanjutnya diharapkan dapat memasukan faktor lain yang diduga berpengaruh terhadap belanja daerah seperti Dana Alokasi Umum.

2. Disarankan untuk Pemerintah agar Pendapatan Asli Daerah dapat meningkat, maka pemerintah Kota Banda Aceh untuk meningkatkan usaha pemungutan Pajak Daerah, Retribusi Daerah dan lain-lain PAD yang sah secara intensif dan aktif sampai persentasenya maksimal.

\section{DAFTAR PUSTAKA}

Davey, K.J. 2008. Pembiayaan Pemerintah Daerah: Praktek-Praktek Internasional dan Relevansinya bagi Dunia Ketiga. Alihbahasa: Anarullah. dkk. Jakarta: UI-Press.

Devas, N., Binder, B., Booth, A., Davey, K. dan Kelly, R. 2009. Keuangan Pemerintah Daerah di Indonesia. Alihbahasa: Marsi Maris. Jakarta: UIPress.

Ghozali, I. 2007. Aplikasi Analisis Multivariate Dengan Program SPSS. Semarang: Badan Penerbit Universitas Diponegoro.

Gujarati, D.N. 2003. Basic Econometrics. New York: McGraw-Hill Company.

Halim, A. 2004. Bunga Rampai Manajemen Keuangan Daerah. Edisi Revisi. Yogyakarta: UPP AMP YKPN.

Halim, A. 2007. Problem Desentralisasi dan Perimbangan Keuangan Pemerintahan Pusat dan Daerah. Edisi Pertama. Yogyakarta: Sekolah Pasca sarjana UGM.

Isdijoso, B. 2002. Analisis Kebijakan Fiskal pada Era Otonomi Daerah (Studi Kasus: Sektor Pendidikan di Kota
Surakarta). Kajian Ekonomi Dan

Keuangan. Vol. 6, No. 1, hal. 22-56.

Kesit, B.P. 2009. Pajak dan Retribusi Daerah. Yogyakarta: UII Press.

Koswara, E. 2001. Otonomi Daerah Untuk

Demokrasi dan Kemandirian

Rakyat. Jakarta: Yayasan Pariba.

Mardiasmo. 2002. Otonomi Daerah dan

Manajemen Keuangan Daerah.

Yogyakarta: Andi.

Masdjojo dan Sukartono. 2009. Pengaruh

Pendapatan Asli Daerah dan Dana

Perimbangan terhadap Belanja Daerah

serta Analisis Flypaper Effect

Kabupaten/Kota di Jawa Tengah

Tahun 2006-2008. Telaah Mana-

jemen (TEMA). Vol. 6, No. 1, hal. $32-50$.

Pratiwi, N. 2007. Pengaruh Dana Alokasi

Umum (DAU) dan Pendapatan Asli

Daerah (PAD) terhadap Prediksi

Belanja Daerah pada Kabupaten/Kota

di Indonesia. Skripsi. Yogyakarta:

Fakultas Ekonomi UII.

Redjo, S.I. 2008. Keuangan Pusat dan

Daerah. Bandung: BKU Ilmu

Pemerintahan Fakultas Ekonomi Pasca

sarjana Kerjasama Universitas

Padjajaran.

Republik Indonesia. Keputusan Menteri

Dalam Negeri Nomor 29 Tahun

2002 tentang Anggaran Pendapatan

dan Belanja Daerah. Jakarta.

Republik Indonesia. Peraturan Pemerintah

Dalam Negeri Nomor 13 Tahun

2006 tentang Pedoman Pengelolaan

Keuangan Daerah. Jakarta.

Republik Indonesia. Peraturan Pemerintah

Nomor 58 Tahun 2005 tentang

Pengelolaan Keuangan Daerah.

Jakarta.

Republik Indonesia. Undang-Undang

Nomor 17 Tahun 2003 tentang

Keuangan Negara. Jakarta.

Republik Indonesia. Undang-Undang

Nomor 22 Tahun 1999 tentang

Pemerintah Daerah (Otonomi

Daerah). Jakarta. 
Republik Indonesia. Undang-Undang Nomor 32 Tahun 2004 tentang Pemerintahan Daerah. Jakarta.

Republik Indonesia. Undang-Undang Nomor 33 Tahun 2004 tentang Perimbangan Keuangan antara Pemerintah Pusat dan Daerah. Jakarta.

Republik Indonesia. Undang-Undang Nomor 33 Tahun 2004 tentang Perimbangan Keuangan antara Pemerintah Pusat dan Pemerintahan Daerah. Jakarta.

Saragih, J.P. 2005. Desentralisasi Fiskal \& Keuangan Daerah dalam Otonomi. Jakarta: Ghalia Indonesia.

Simanjuntak. O. 2007. Hukum Pajak. Medan: Nomensen-press.

Sugiyono. 2012. Statistika untuk Penelitian.

Cetakan 19. Bandung: CV. Alfabeta.

Sumarmi, S. 2008. Pengaruh Pendapatan Asli Daerah, Dana Alokasi Umum dan Dana Alokasi Khusus terhadap Belanja Modal di Provinsi
Yogyakarta. E-Jurnal Manajemen UII, Vol. 5, No. 2, hal. 1338-1367.

Sumitro, R. 2007. Azas dan Dasar Perpajakan. Bandung: Eresco.

Syamsi, I. 2008. Dasar-Dasar Kebijaksanaan Keuangan Negara. Jakarta: Rineka Cipta.

Uyanto, S.S. 2010. Pedoman Analisis Data dengan SPSS. Jakarta: Ghalia Indonesia.

Widjajakosoema, A.S. 2011. Pengaruh Pendapatan Asli Daerah (PAD) terhadap Belanja Daerah Pemerintah Kota Kediri Periode 2005-2009. Cahaya Aktiva. Vol. 1, No. 1, hal. 10-15.

Yani, A. 2008. Hubungan Keuangan Antara Pemerintah Pusat dan Daerah di Indonesia. Jakarta: PT. Rajagrafindo Persada.

Yuwono, S., Indrajaya, A.(T). dan Hariyandi. 2005. Penganggaran Sektor Publik. Surabaya: Bayumedia Publising. 